\title{
An Analysis of People's Political Participation in Region Head Election 2017 in Lanny Jaya Regency, Papua Province
}

\author{
Siti Khikmatul Rizqi ${ }^{1}$, Dines Muni ${ }^{1}$ \\ \{sitikhikmatulrizqi@yahoo.com\} \\ Universitas Amal Ilmiah Yapis Wamena ${ }^{1}$
}

\begin{abstract}
This article aims to discovering people's political participation in the elections 2017 in Lanny Jaya Regency, Papua Province. This research is important as an evaluation, consideration and advice to the Regional Government in particular General Elections Commission. Because of efforts to increase the political participation of society must be based on strong analysis and argumentation. This is due to the need to realize the strategic step in improving the quantity and quality of public political participation in elections and improvement of the election system better. This research implemented in the District of Makki Lanny Jaya, Papua. Research results, political participation society Lanny Jaya on the elections in 2017 is basically influenced by the mechanics of the election either with the noken LUBET system (General Outright Free open) as well as the election with a ballot box LUBER (General Outright Non Confidential). The election mechanism with a system that has the custom of noken starts with the burn party rock. While the factors cause communities not participating is caused is not listed in the list of Electors and the distance between houses with the polling stations so far, distrust toward prospective Regent/Vice Regent of either lack of trust towards campaign promises, are not interested in the vision and mission that is offered to the existence of a noncertainconnvinced society does when he chose would influence or change for the community.
\end{abstract}

Keywords: Political Participation, Elections In 2017

\section{Introduction}

The political participation of the public (the electorate) is an important aspect in an order of the country's democracy. Political participation affect the legitimacy of the community against the operations of a Government. In the elections for example political participation affect the legitimacy of the community to the candidate or candidates elected. Every society has the preferences and interests of each to determine their choice in Elections. It could be said that the future of public officials elected in an Election depends on the preferences of society as voters. Political participation of the community in the elections can be seen as the evaluation and control of the community against the leaders or the Government.

The efforts of increasing the political participation of the community must be based on a strong analysis and argumentation. This is due to the need to realize a strategic step in 
improving the quantity and quality of participation of the community in political elections and the perfecting of the system of Elections to a better future. That means argumentation and analysis must be based on birth, first, methodology or framework of thought appropriate for understanding the dynamics of political participation, as well as the second, based on strong with sensitivity towards the growing Dynamics-Dynamics in the area of economic, administrative, political, and social and cultural.

With that awareness, then the whole of the report is structured systematically which at the beginning will be discussed the substance of public political participation in the elections in democratic countries. That the elections were a mechanism adopted in a democratic system to produce leaders or public officials. Because the basic principles as conscious society to participate in the elections must be formed in people. Aim of research on this part is trying to put the essence of the people (voters) in the system of democratic governance. Next will be revealed in the next step of how the methods of research and the flow of analysis used in this research. This section is made up of academic awareness that the methodology and the appropriate analytical framework, will determine the accuracy of the findings and recommendations in this research. To construct a proper analysis and remained standing on the context (geopolitical and socio-cultural space Lanny Jaya Regency) then this is also the underlying research with in-depth discussion on the background of Lanny Jaya regency context as the scope of this research. The goal is that the dimensions of context can be included as a unit analyst who also participated in the influential in voter participation that will produce a more comprehensive analysis. After completing the method and workflow analysis, and background context, the next step to try exploring the turnout in the election is based on the findings of the field. At the end of the elaboration results, will produce conclusions. Based on the above, the authors are interested to do research, to determine the level of political participation of the people with the title " An Analysis Of People's Political Participation In Region Head Election 2017 In Lanny Jaya Regency, Papua Province.

Equal opportunity for every citizen in every decision-making, has been affirmed in the Constitution of 1945.

The political participation of society in the formation of legislation or regulation is reinforced by Article 96 of the Law of the Republic of Indonesia Number 12 of 2011 on legal drafting legislation states that the public has the right to provide input in writing or verbally in the formation of legislation. Article 139, paragraph (1) of Law Number 32 Year 2004 on Regional Government there is also a provision that the public has the right to provide input in writing or verbally in the framework of the preparation or discussion of the draft law. Law No. 32 of 2004, as well as the explanation can be seen that: 1. The people berhakmemberikan inputs for the preparation or discussion of the draft law; 2. Put these communities can be done orally or in writing.

The participation or the participation of citizens in participating determining the implementation and governance, is the primary dimension in the political process. Participation is a minimum requirement, countries implementing democratic political system. Burkens [1] says everyone has political rights such as the right to freedom of expression and assembly.

Soemantri argues that the idea of democracy manifesting itself in five ways, two of which are government must be open (open baarheid van bestuur) and the possibility of interested people submit complaints about the actions of officials are considered harmful. Public participation is a form of participation or community involvement in the development program. This community participation shows that people feel involved and feel part of the 
development. This will be very positive impact on the successful implementation of a development program [2].

As citizens, political participation has been guaranteed by the 1945 Constitution as the constitutional basis. Article 27 UUD 1945, states rights and obligations which are guaranteed in politics and governance. This article asserts that every citizen has the same status in law and government, as well as mandatory menjunjungnya with no exceptions. Would be the case with the Human Rights Act Law No. 39 of 1999 explicitly states that every Indonesian citizen has the right to participate in government, among others entitled to have and to vote in elections. Then, entitled to participate in government by directly or through representatives chosen freely, can be raised in any position in the government, and reserves the right to submit opinions, requests, complaints, and or suggestions to the government in the implementation of good governance, effective, and efficient, both orally and in writing (Article 43 and Article 44).

Juliantara, explains the benefits of participation as: Voice, referring to the rights and actions of citizens to express their aspirations, ideas, needs, interests and demands of the immediate community as well as government policies. Access, means that influence and determine the policies and engage actively manage public goods, including publik.Control citizens' access to services, that is how people willing and able to engage to supervise the government tasks. So that will form a government that is transparent, accountable and responsive to the needs of society.

Burby [3] in Baker, Addams and Davis said that public participation can produce better government policy because: 1 . The principle of fairness and equality. 2 . It is the right of people to receive information and to express their views related to government policy. 3 . There is a need to represent the interests of groups of people who are weak and powerless. 4. There is a need to capture what is really desired by the community. The benefits of public political participation, are:

1. To provide a better foundation for public policy making.

2. Ensure the implementation of more effective because people know and are involved in public policy making.

3. Improving the trust of citizens to the executive and legislative branches.

4. Efficiency of resources, because the public participation in formulating public policy and determine public policy, the resources used in the dissemination of public policy can be saved.

Many experts who have conducted a study of the concept of political participation despite their ultimate goal is the same, but often different from the aspect of the approach. According to Ramli (2013), Understanding of participation is very complex, so it is not easy to define in detail. It is seen from the notion put forward some experts the following: 1. Participation is a voluntary contribution from the public on the government's program to support national development without participating in the making of the program itself or criticize the contents neighbor. 2. Participation in the broadest sense is to sensitize the public and increase the sensitivity and ability to respond to development programs and also encourage local initiatives. 3. Participation includes community involvement in the decision making process and the implementation of the program, take part in the evaluation of the results and are involved in the program.

1. Participation in active involvement in decision making as far as things that concern them.

2. Participation is the involvement of society is entitled and obliged to participate in solving problems (health), is responsible for obtaining needs (health), mobilizing local 
resources and propose a new problem-solving, as well as create and maintain a local organization.

3. Participation is an active process, meaning that the person or group concerned takes the initiative and ensure its authority (autonomy) to do so.

4. Participation is an organized effort to master (controlling) the resources and institusionsl set up in certain social situations, a group or movement that had excluded them from the domination / control them.

Globally recognized the elections arena to establish a representative democracy and to hold regular changes of government. According to the theory of democracy, minimalist (Schumpetrian), the election is an arena that can accommodate competition (contestation) between political actors to come to power; political participation of the people to make choices; liberalization of rights-civil and political rights of citizens [4]. Democracy also outlined that election is opportunity for opposition parties and the people to run the mechanism of checks and balances against the ruling party (the ruling party). Although many people assessing conceptions of democracy such as this tend to be minimalist, but the minimalist democratic practice has established a system to define / filling public positions in all democratic countries. This means that the elections had been institutionalized and institutional and become a universal mechanism in the political systems in democratic countries. In the context of the elections, the election mechanism is said to be democratic if it meets a number of parameters [4]: 1). election; 2). The rotation of power; 3). Recruitment openly; 4). Public accountability. Referring to this view, the more clear that the spirit of democracy requires broad participation space and have constructed our democratic system in a direct democracy in which the people directly participate to determine political choices without represented.

In modern democracies, the implementation of direct elections is not only the procedure but also a necessity to repair and correct errors in the execution of government. Selection of quality should have criteria that provide the opportunity for people to; a. Choosing between the different policies bid and parties or candidates competing b. Ask elected officials accountable for their actions, and c. Transform the symbolic conception (popular sovereignty) into real action the real (Boulder) At this point the conception of the universality of the individual in a democracy (have the same rights) must be upheld. That all citizens have the same chances and opportunities to evaluate and determine the leader. So that political participation in this case the participation of citizens in elections is important. On the same side a good understanding of the strategic roles of citizens will promote the quality of democracy.

\section{Method}

Location and time research, based problems studied, the authors establish research sites in the District Makki Lanny Jaya regency of Papua Province.

Types and sources of data, First Data Primer, Data direct obtained from respondents in which members of the district communities into the sample and then analyzed data include data on the respondents, data on the participation of the district communities in election activity data and the factors that influence people's participation in elections, and data on education, age, occupation, and other information that necessary. Second, secondary data, update data and other information that is used to explain the problems to be studied, the data obtained from the office of District Chief Lanny Jaya Regency Makki and the Voting 
Committee (PPS). The data includes data on population, data on the location of the study, data from the local elections (Regent and Vice Regent).

Polulasi and samples, as for the population in this study is Makki District community who have the right to vote (aged 17 years or older, or married) amounted to 2,336 people based on the data Lanny Jaya Regency. Samples, In taking the data researchers determined sampled using Slovin Theory (in Husein Umar, 2014: 146) with Slovin the following formula:

$$
\begin{aligned}
& \mathrm{n}=\frac{\mathrm{N}}{1+\mathrm{Ne}^{2}} \\
& \mathrm{n}=\frac{2336}{1+2336(0,1)} 2
\end{aligned}
$$

$\mathrm{n}=95,89=96$ (Rounding). The sampling technique used is random sampling (choose randomly).

Data collection technique. In this reserch, the authors used data collection techniques by providing in-depth interviews, spread Questionnaire (questionnaire), and observation. Data analysis.

The technique of data analysis in this research is using descriptive analysis technique by using a percentage by the following formula.

$$
\mathrm{P}=\frac{\mathrm{F}}{\mathrm{x}} \mathrm{100 \%}
$$

\section{Result and Discussion}

By paying attention to the research objectives, in this chapter will be presented the results of the analysis on the analysis of public political participation in local elections in 2017 Lanny Jaya Regency Papua Province.

\subsection{Overview of Research Sites}

Lanny Jaya Regency is one of regencies in Papua Province. Lanny Jaya regency capital is Tiom with area is $2,248 \mathrm{~km} 2$ and is bordered by the administrative area:

- North: Kanggime, Karubaga and Goyage, Tolikara danKelila, Central Memberamo District;

- South: Mbuwa, Yigi, Mugi, Mapenduma and Geselma, nduga regency;

- West: Illaga, Ilu

- East: Asologaima, Jayawijaya

Most Lanny Jaya regency is located in the interior. Lanny Jaya Regency Society outlines work in agriculture, construction and trade workers. Agriculture as the largest absorber of employment. Economic segments of society dominated by the agricultural sector has been supported by the infrastructure of roads, bridges that provide access to other areas, but in the city and inter-district roads have not been paved, and traditional markets are becoming erea sales of agricultural products. This condition shows that economic mobility in Lanny Jaya Regency has started to move so that it also affects the way people live Lanny Jaya regency which tend to be consumptive. At this point the correlation can be drawn referring to Huntington's view that in economies improved tendency to implement democracy, the better, the more likely masrakat participation would be good because it is supported by economic and cultural aspects of Lanny Jaya Regency. 
3.2 Implementation Mechanism Nokens System Based Practices Applied to Lanny Jaya Election 2017

Research found some models noken system implementation mechanism based practices applied in local elections in the district of Lanny Jaya greatly affect voter participation, as follows:

Table 1. Mechanism Nokens system on Election 2017

\begin{tabular}{|c|c|c|}
\hline No. & Mechanism Nokens system & Things That Need to be Considered \\
\hline 1. & $\begin{array}{l}\text { Chiefs and the community do } \\
\text { coalparty before the elections. On } \\
\text { polling day, voters gathered } \\
\text { around the polling area, then } \\
\text { chieftain requested a number of } \\
\text { ballots to KPPS based on the } \\
\text { number of participant is, ballots } \\
\text { are inserted into the camshaft to be } \\
\text { given to candidate pairs in TPS }\end{array}$ & $\begin{array}{l}\text { - Implementation of a coal party to make } \\
\text { - } \text { Poices candidate pairs } \\
\text { - } \text { Voting is done by representatives of } \\
\text { - } \quad \text { Ballots not pierced by the representatives } \\
\text { - } \quad \text { Sounds incorporated into the camshaft } \\
\text { - } \quad \text { KPPS cast their ballots thereafter }\end{array}$ \\
\hline 2. & $\begin{array}{l}\text { Voters do coal-party at home or } \\
\text { inthe district capital, and several } \\
\text { representatives came to the polling } \\
\text { stations and asked KPPS number } \\
\text { of ballot papers on behalf of the } \\
\text { number of people it represents, } \\
\text { then punched ballots directly } \\
\text { inserted into the camshaft to be } \\
\text { submitted to a selection candidate } \\
\text { pairs. }\end{array}$ & $\begin{array}{l}\text { - Implementation of a coal party to make } \\
\text { choices candidate pairs } \\
\text { - } \text { Position voters outside the polling station } \\
\text { - Only representatives who came to the } \\
\text { polling stations and a ballot } \\
\text { - Ballots not pierced by the representative of } \\
\text { Ballots inserted into the camshaft } \\
\text { - KPPS cast their ballots later }\end{array}$ \\
\hline 3. & $\begin{array}{l}\text { Chieftain along party people do } \\
\text { burn stone before the election. } \\
\text { Noken prepared in a number of } \\
\text { polling stations replace the } \\
\text { function of the ballot box. In each } \\
\text { polling station, the number of } \\
\text { camshaft is adjusted based on the } \\
\text { number of candidate pairs. Each } \\
\text { candidate pairs represented by a } \\
\text { camshaft. Then voters were at the } \\
\text { polling stations took the ballots } \\
\text { and inserting his ballot into Noken } \\
\text { choice. }\end{array}$ & $\begin{array}{l}\text { - } \\
\text { - } \text { determinementation of a coal party to } \\
\text { - } \quad \text { Position of voters around the TPS } \\
\text { - } \quad \text { Not punched ballots by voters } \\
\text { - } \quad \text { Ballots put in a particular camshaft } \\
\text { - } \quad \text { KPPS cast their ballots later }\end{array}$ \\
\hline
\end{tabular}




\begin{tabular}{|c|c|c|}
\hline 4. & $\begin{array}{l}\text { Chiefs together people burn stone } \\
\text { meakukan party before the } \\
\text { elections. Noken prepared in a } \\
\text { number of polling stations replace } \\
\text { the function of the sound. In each } \\
\text { polling station, the number of } \\
\text { camshaft is adjusted based on the } \\
\text { number of candidate pairs. Each } \\
\text { candidate pairs represented by a } \\
\text { camshaft. Then voters were at the } \\
\text { polling stations took the ballots, } \\
\text { then. Punching and inserting his } \\
\text { ballot into noken choice. }\end{array}$ & $\begin{array}{l}\text { - Implementation of a coal party to } \\
\text { makechoices candidate pairs } \\
\text { - Position voters around polling stations } \\
\text { - Voting is done each voter } \\
\text { - Punched by a voter ballot papers } \\
\text { ballotpapaers inserted into a specific } \\
\text { camshaft } \\
\text { - The camshaft for one candidate pairs }\end{array}$ \\
\hline
\end{tabular}

\subsection{Character Respondents}

Descriptive analysis is used to analyze the characteristics of respondents. Respondens involved in this research that the district communities Makki Lanny Jaya regency, the people who have met the requirements as mandatory to select which had been aged 17 years or has been married. In this study of 96 people who were taken from each village in the district of Lanny Jaya Regency Makki that a balance of the number of voters in each ward. The informant research in the following table:

Table 2. Distribution of Respondents by Number of Voters

\begin{tabular}{|c|l|c|}
\hline Number & \multicolumn{1}{|c|}{ Village } & The Number Of Respondents \\
\hline 1 & Kemiri & 16 \\
\hline 2 & Mamiri & 11 \\
\hline 3 & Kotaramur & 11 \\
\hline 4 & Londu & 11 \\
\hline 5 & Tengenawi & 11 \\
\hline 6 & Yorenime & 14 \\
\hline 7 & Yibame & 11 \\
\hline 8 & Waganega & 11 \\
\hline & TOTAL & 96 \\
\hline
\end{tabular}

Characteristics of data collection respondents by sex, age and education level.

1) Characteristics of Respondents by Gender

The percentage of respondents by sex can be seen in the table below:

Table 3. Characteristics of Respondents by Gender

\begin{tabular}{cccc}
\hline Number. & Gender & Frequency & Percentage (\%) \\
\hline 1. & Male & 55 & 57,29 \\
2. & Female & 41 & 42,71 \\
\hline
\end{tabular}




\begin{tabular}{ccc}
\hline Total & 96 & 100 \\
\hline Source: Data processed researcher, 2018 &
\end{tabular}

From table 3. shows that the number of respondents by sex as many men as women as much as $57.29 \%$ and $42.71 \%$ of the total of 96 people.

2) Characteristics of Respondents by Age

The percentage of respondents by age can be seen in the table below:

Table 4. Characteristics of Respondents by Age

\begin{tabular}{cccc}
\hline Number & Age (year) & Frequency & Percentage (\%) \\
\hline 1. & $17-30$ & 68 & 70,83 \\
2. & $31-44$ & 13 & 13,54 \\
3. & $45-58$ & 11 & 11,46 \\
4. & $59-70$ & 4 & 4,17 \\
& Total & 96 & 100 \\
\hline
\end{tabular}

Source: Data processed researcher, 2018

From table 4 . shows that the number of respondents by age 17-30 year as much as $68 \%$, age 31- 44 year as much as 13,54\%, age $45-58$ year as much as $11,46 \%$ and age $59-70$ year as much as $4,17 \%$ of the total of 96 people

3) Characteristics of Respondents by Education Last

The percentage of respondents by education last can be seen in the table below:

Tabel 5. Characteristics of Respondents by Education Last

\begin{tabular}{clcc}
\hline Number & \multicolumn{1}{c}{ Education Last } & Frequency & Percentage (\%) \\
\hline 1. & No School & 15 & 15,65 \\
2. & Elementary school & 9 & 9,38 \\
3. & Lower Secondary School & 17 & 17,71 \\
4. & Upper Secondary School & 53 & 55,21 \\
5. & D3/ bachelor & 2 & 2,08 \\
& & 96 & 100 \\
\hline
\end{tabular}

Source: Data processed researcher, 2018

3.4 Respondents Answers Related Factors Influencing Public Attitudes in Choosing the Year 2017 local elections.

Table 6. Factors Influencing Public Attitudes in Choosing the Regional Head Election Year 2017 Number Influencing Factors in Choosing Frequency Percentage

\begin{tabular}{clcc}
\hline Number & Influencing Factors in Choosing & Frequency & Percentage \\
\hline 1. & $\begin{array}{l}\text { Attracted by the vision and mission } \\
\text { of the candidate selected }\end{array}$ & 47 & 67,14 \\
2. & $\quad$ Candidates were clean & 4 & 5,71 \\
3. & $\begin{array}{l}\text { Has received money or gifts from } \\
\text { candidates }\end{array}$ & 7 & 1,43 \\
4. & $\begin{array}{l}\text { Have blood relations or brothers } \\
\text { bound by candidate }\end{array}$ & 1 & 10 \\
5. & $\begin{array}{l}\text { Have a common ethnic } \\
\text { 6. }\end{array}$ & 3 & 1,43 \\
Having the same religious / belief & $\begin{array}{l}\text { groups } \\
\text { Due to the request or the } \\
\text { government's insistence village } \\
\text { /district }\end{array}$ & 3 & 4,29 \\
& &
\end{tabular}




\begin{tabular}{clcc}
\hline 8. & The demand of parents / relatives & 2 & 2,86 \\
9. & $\begin{array}{l}\text { Having a profession with potential } \\
\text { equation }\end{array}$ & 0 & 2,86 \\
10. & $\begin{array}{l}\text { Sympathy with the physical shape } \\
\text { figure candidates }\end{array}$ & 2 & 100 \\
$\quad$ Total & 71 & \\
& \multicolumn{2}{c}{ Source: Data processed researcher, 2018 }
\end{tabular}

There is 67.14 percent of respondents were influenced by the vision and mission of political parties and candidates to make his choice in the election of regional head candidate in 2017. According to the respondents that the vision and mission submitted by political parties and candidates in the election of candidates for regional head believed to give hope to progress region including changes in the conditions being experienced at the time. Respondents judge he chose a particular candidate at the moment in the polls because it is affected by the promises delivered. The promises were delivered very in tune with the needs of the respondents craved namely improving the welfare namely in the fields of education, health and economy as well as the improvement of infrastructure.

There are 5.71 percent of respondents who said that the factors that influence in determining the choice in the election of regional head candidate in 2017 due to a clean candidate.

There are 1.43 percent of the respondents who stated that he chose at the time of voting at polling stations affected by the giving of money or other gifts shortly before voting. Respondents chose due to repay on the provision of calon.Sebagian respondents admitted that receiving money or gifts of pigs from candidates not dilakukanya only one candidate. However, all candidates had to give money and gifts but the chosen pig respondents was that the candidate provides the highest number of pigs. Respondents said that the cause of the respondents chose a particular candidate because of money or gifts that is due to the interest of the party culture stone fuel.

There are 10 percent of respondents who said that the factors that influence in determining the choice in the election of candidates for regional head candidates in 2017 due to the bloodrelated or dependent relatives with the candidate.

There are 1.43 percent of respondents who said that the factors that influence in determining the choice in the election of 2017 caused calonkepala area has kesamaaan ethnic candidates with potential are 4.29 percent of the respondents said that the factors that influence in determining the choice in the election year prospective head region 2017 caused that a common candidate for the religious / belief groups with candidates.

There are 4.29 percent of respondents who said that the factors that influence in determining the choice in the election of regional head candidate in 2017 caused such candidates for their request or the government's insistence village / district.

There is a 2.86 per cent of respondents who said that the factors that influence in determining the choice of candidates daearah election in 2017 caused such candidates for their request of parents or relatives.

There is a 2.86 per cent of respondents who said that the factors that influence in determining the choice in the election of regional head candidate in 2017 due to sympathy with the physical shape / figure candidates.

3.5 Answer respondents related factors into public cause opt in the 2017 local elections.

Table 7. Factors Influencing Public Attitudes Not Choosing the Regional Head Election Year 2017

\begin{tabular}{llll} 
Number & Factors Affecting not Choose & Frequency & Percentage $(\%)$ \\
\hline
\end{tabular}




\begin{tabular}{|c|c|c|c|}
\hline 1. & $\begin{array}{l}\text { Do not believe the promises of } \\
\text { candidates }\end{array}$ & 4 & 15,38 \\
\hline 2. & $\begin{array}{l}\text { Not interested in the candidate's } \\
\text { vision and mission }\end{array}$ & 2 & 7,69 \\
\hline 3. & $\begin{array}{l}\text { Not listed in the DPT } \\
\text { (Permanent Voter Register) }\end{array}$ & 12 & 50 \\
\hline 4. & Did not receive invitations & 0 & 0 \\
\hline 5. & $\begin{array}{l}\text { No candidate who gave } \\
\text { money or gifts }\end{array}$ & 1 & 3,85 \\
\hline 6. & $\begin{array}{l}\text { The distance between the } \\
\text { houses with TPS very much }\end{array}$ & 6 & 23,08 \\
\hline 7. & Preferring to work at election time & 0 & 0 \\
\hline 8. & Feel no benefit when choosing & 0 & 0 \\
\hline 9. & Physical limitations & 0 & 0 \\
\hline 10. & Another factor & 0 & 0 \\
\hline & Total & 26 & 100 \\
\hline
\end{tabular}

Source: Data processed researcher, 2018

There is 15.38 percent of respondents said no vote in the selection of candidates Regional Head in 2017 due not believe the promises of a candidate. There are 7.69 percent of respondents who said not to vote on the election of regional head candidate in 2017 due not interested in the vision and mission of the candidate.

There are 50 percen of respondent who said not to vote in the election year prospective head region 2017 caused not registered in DPT (Permanent Voters List). There are 3.85 percent of respondents who said not to vote on the election of regional head candidate in 2017 caused no candidate gives money / gifts.

There is 23.08 percent of respondents said that not voting on the election of regional head candidate in 2017 due to the distance between the house with TPS very much.

\subsection{Discussion}

of the political participation of the people is a form of manifestation of democracy. Countries without political participation tends to be authoritarian and centralized society. In the context of governance, participation puts the actual position [5] First; society is not a slave (client) but as a citizen (citizen). If the servant showed total obedience, then the concept of citizens consider that every individual is a whole person and has full rights to own. Second; society is not in a position governed but as a partner of the government in managing government and development. Third: participation is not government handouts but as a right of the citizen. Fourth: the community rather than as merely passive objects beneficiaries of government policy, but as an actor or an active subject determining policy.

The main reason why public participation is very important to have properties. First, community participation is a means to obtain information about the conditions, needs and attitudes of the local community, without whose presence the development programs and projects will fail. Second, the public will trust the project or program if they feel involved in the process of preparation and planning, because they would rather know the ins and outs of the project and will have a sense of belonging to the project. Third, one might think that it is a democratic right when people are involved in the development of their own communities. Can 
feel that they too have the right to participate in providing advice in determining the kind of development that will be implemented [6].

The idea of society in policy making and government planning is important to remember is they who see, hear and feel directly the facts on the ground. For example, in the case of the determination of taxes and charges, before stipulated there should be consultation with the community. It is very important that when the policy was about to be implemented there will be no public objections. If konstulasi with society do then it is likely that policy will have the support of society at the time be implemented The importance of political participation is done in the framework of good governance in Lanny Jaya Regency.

Community participation has the advantage of the social, political, planning and other advantages, namely:

1. From the social point of view is to enable urban populations tend individualistic, do not commit and in extreme cases alienated. In the process of this participation, simultaneously promoting community spirit and sense of cooperation and engagement.

2. In terms of politics, the participation of more promoting participatory democracy than the elected representatives (representative democracy) as a democratic right of every person and thus the general public, to participate in the decision-making process. Public participation will also help the council (Counselors) and other decision makers to get a clearer picture of the demands and aspirations of their constituents or all of the parties who will be affected, and the sensitivity of the decision-making can be maximized if handled properly.

3. In terms of planning, participation provides a forum for exchange of ideas and priorities, assessments will be public interest in the dynamics and the receipt of proposals of planning [7].

Public political participation in the elections also determine the direction and progress of a nation. The quality of political participation will be determined whether all the people who are qualified shall choose to vote on, whether the public is given access or facilities in selecting and whether people can choose leaders who are actually qualified based on confidence and trust in the candidate he chose.

The quality of the election will be determined also by the quality of the voters themselves. The better the quality of the voters, the process and the election results will be more quality as well. The results showed that the attitude of the voters affected by vision, mission and programs of the candidates head daerah. Attitude voters in determining the choice was influenced by the transaction, the same beliefs, and ethnic similarities even as the government's insistence village and district governments. Voters do not care what the candidate promised, but interested in the financial aspect and kinship with the candidate.

Election Problems in the real Lanny Jaya Regency technical processes that influenced the election mechanism, first with the camshaft system that starts with coal-party. Where the food was served at the party in the form of pigs originating from prospective candidates, candidates who donated pork most it will be won / been and will be given a ballot (In this case, the party fueled stones were used to determine the choice of candidate pairs so that people do not participate directly but through a representative). Second, well-marked ballot papers by representatives and individuals, but who will cast their is KPPS. Ballots that have not been punched and then stored frequently stolen by the person who lost and result in inter-ethnic conflicts. Third, punched ballots by voters individually, but put on a specific camshaft (if voters coblos candidate pairs 1 then the ballot will be included on Noken candidate pairs 1 ), so that the voter's choice remains unknown to the public (not secret). This has led to conflicts between family or fam. 
However, in some polling stations existing carry out the elections in LUBER (General Direct Non Confidential). LUBER of elections is usually done by people who have adapted to the newcomers, the people residing in the territory of the district capital and educated who already know the meaning of democracy.

The results or substance of the elections are still far away as expected. The final results of the elections are expected actually gave birth to the ideal leader. The fact has been that in addition to the implementation process is still less than professional, elected regent produced through the electoral process is still considered to have low quality, ranging from the limitations of professionalism leadership, legally problematic and the lack of progress of the area that led to the current ending the occupation.

The weakness of the elections also caused by the regulation itself namely Law No. 10 Year 2016 regarding the Election of governors, regents and mayors. These requirements are limited to the normative provisions concerning the requirements of executive candidates and not the provisions of substantive requirements. Act was apparently not designed to filter out and give birth to a quality leader. To create a quality leader should begin from the regulations that govern them. There will also have special requirements especially about leadership experience. That is why participants of the elections more followed by candidates who have not been established in terms of leadership so that the target of the entrepreneurs who have big capital to hold it. Therefore, the election law needs to be revised to require the special requirements for candidates / vice regent namely leadership experience as government leadership experience, community organizations, political parties, companies or other leadership experience that could strengthen the experience of being a regent. Election Law should be designed to limit those with less experience to become candidates. In addition to strengthening the regulation of elections then things need to be addressed as well is the institutional strengthening of the organizers of the elections. Experience in several areas, not berkualitasnya the process of conducting the elections is due to the unprofessionalism of the organizers of the election itself, especially at the level of the ad hoc committee. Election organizers at this level are PPK, PPS, and KPPS many civil servants and recruitment mechanism conducted by involving (recommendation) so village officials so easily interfered by political forces who are competing let alone one of the candidates is the incumbent regional head. Consequently, many of the violations occurred as a result of a conspiracy (intimidation), an organizer with one of the political forces.

Organizers at this level often do not have the experience in relation to the work face. Recruitment is done at the time of the elections process Lanny Jaya Regency is running be one reason for the limited experience of them. In some cases, already conducted voting at the polling station, but the organizers have not had time to follow the technical assistance (Technical Guidance) the organization of the elections, so that the duties and functions performed potluck. The results of the investigation, as the description above mentions the main factors causing people not to participate is caused not registered in DPT (Permanent Voters List). This happens because at the time of data collection community voters were not in place, for example; people are learning in Wamena town in the district for expansion, especially in Lanny Jaya Regency college yet; semi-nomadic culture (patterns of life moving from one place to another, but it has been accompanied by a sedentary life while). This is due to the fact that they have started to identify the ways to process and distribute foodstuffs although still traditional, in this case the community settled until a few months in the city of Wamena to earn a decent income.

There is 23.08 percent of respondents said that not voting on the election of regional head candidate in 2017 due to the distance between the house with TPS very much. Access the 
majority of the main transport is by foot, so that the main road connecting the villages is a footpath without any hardening. This is the main transport lines Makki district communities. As for the inter-district transport lines connecting roads already exist mostly in the form of hardening and began to be paved. Geographical conditions of the area is hilly, winding and steep, especially in areas prone to frequent attacks by separatists who do not want the implementation of the regional head elections. This resulted in people who lived far from polling stations (TPS) be reluctant to participate. Population density of 39.74 people $/ \mathrm{km} 2$, also affects the community in participating, where the distance between home / family makes communication less smoothly so hard single political socialization is achieved.

Another factor that causes people not to participate in voting at elections in 2017 due to mistrust of the candidate regent / vice regent both distrust of campaign promises, not interested in the vision and mission that offered up their ketidaknyakinan society does when he chose to take effect or changes to society. In addition to causing people do not choose due ketidapercayaan the regent and deputy regent candidate Lanny Jaya Regency, public mistrust also turned out to be the cause of high transaction mode or gifts from candidates to voters. Informants felt that the process of recruiting candidates for regent / vice regent Lanny Jaya Regency as experienced several times elections Lanny Jaya Regency very concern. KPU did not seem concerned with the capacity and professionalism of candidate for regent / vice regent at the time of recruitment and are usually considered is te magnitude of the opportunities the election of candidates for regent / vice regent concerned. Motivated political parties that the greatness of a political party is not determined on kuliatas but is determined by how the vote or seats that would be obtained in an arena elections. This then is the cause that the parties prefer to recruit people to become a candidate for regent / vice regent Lanny Jaya Regency a chance to win despite the lack of experience of leadership become a candidate for regent / deputy regent.

That is why the political party membership requirement is an important requirement to be a candidate regent / deputy regent. Needs be proposed that the requirement of political party membership for candidates / vice regent should never be a member of at least five years of membership. 5-year period shall be filled by a long political education process by ending certificate as proof of participation in the educational process. This 5-year membership requirement will limit the people who suddenly become members of political parties because they want to meet the requirements to be a candidate regent / deputy regent. Then the exodus phenomenon also anticipate the public from one party to another party just before elections.

It is important to do now is to look for patterns that an ideal strategy in the context of political education to the community. How to choose the ideal head of the region and of course the strategy was not only done just before the elections but it must be done on a regular basis long before the Election Day began. Voters should be taught what impact caused because one can choose a leader and how to choose the leaders of the region that benefit him and others.

\section{Conclusion}

Political participation Lanny Jaya Regency society in the elections in 2017 is basically influenced by both the electoral mechanisms that LUBET noken system (General Direct Free

Open) or election by ballot box LUBER (General Direct Non Confidential). Electoral mechanisms with camshaft system customarily begins with a party of a coal tends to affect the participants make their choice by giving money or gifts and because of the demand of parents or the government's insistence village / district, similarity ethnic / tribal, similarities belief / 
eligion. Being in a society overflowing elections likely to be influenced by the vision, mission and candidate pairs candidate pairs clean.

While the causes of people not participating is caused not registered in DPT (Permanent Voters List) and the distance between the houses with TPS very much, distrust of candidates for regent / vice regent both distrust of the promises of the campaign, is not interested in the vision and mission offered until their uncertainty whether the public when he chooses will influence or change for the community.

There are some issues the elections so that the people participate less. First, the Election Requirements confined to the normative provisions concerning the executive candidate pairs requirements and not on the provisions of substantive requirements. Act was apparently not designed to filter out and give birth to a quality leader. Second, the lack of socialization committee elections / KPU to communities linked by public voting provisions. Third, the Operator at this level often do not have the experience in relation to the work face. Fourth, the Commission did not seem concerned with the capacity and professionalism of candidates for regent / vice regent at the time of recruitment and are usually considered is the magnitude of the opportunities the election of candidates for regent / vice regent concerned. Fifth, the high transaction mode or gifts from candidates to voters led to declining public confidence.

\section{References}

[1] P. M. Hadjon, "Pengantar hukum administrasi Indonesia." Gadjah Mada University Press, 2008.

[2] Soetomo, Strategi-Strategi Pembangunan Masyarakat. Yogyakarta: Pustaka Pelajar, 2008.

[3] W. Baker, H. L. Addams, and B. Davis, "Critical Factors for Municipal Public Hearings," Public, 2009.

[4] R. A. Dahl and R. A. Dahl, A preface to democratic theory, vol. 115. Chicago: University of Chicago Press, 1956.

[5] Sutoro, "Ekonomi Politik Pembaharuan Desa Makalah disajikan dalam Pertemuan Forum VII, 'Refleksi Arah dan Gerakan Partisipasi dan Pembaharuan Masyarakat Desa di Indonesia."” Forum Pengembangan Partisipasi Masyarakat (FPPM), Ngawi, Jawa Timur, 2008.

[6] D. Conyers, Suatu Pengantar: Perencanaan Sosial di Dunia Ketiga. Yogyakarta: Gadjah Mada University Press, 1994.

[7] E. Siahaan, "Filosofi Perencanaan Pembangunan Kota Sesuai Paradigma Baru di Indonesia: Hakikat Ilmu Untuk Pemberdayaan dan Peningkatan Peran Serta Masyarakat," in Makalah Falsafah Sains (PPs 702) Program PascaSarjana/S3 Institut Pertanian Bogor, 2002. 